\title{
Kontribusi Perguruan Tinggi Islam Swasta Terhadap Pengembangan Pendidikan Islam
}

\section{FAKHRURROZI}

\author{
STIT Al Aziziyah Lombok Barat NTB
}

071klu@gmail.com

\begin{abstract}
Abstrak: Perguruan Tinggi Nahdlatul Wathan adalah salah satu Perguruan Tinggi Islam yang cukup terkenal dan didirikan pada tahun 1987 di Wilayah Nusa Tenggara Barat. Presesensi untuk memberikan angin segar bagi umat Islam di wilayah tersebut, karena ikut serta memberikan kontribusi bagi perkembangan pendidikan Islam di Wilayah Nusa Tenggara Barat. Peminat perguruan tinggi ini tidak hanya berasal dari umat Islam saja tetapi yang lebih menarik adalah banyak non-Muslim yang juga tertari masuk dan belajar ke Perguruan Tinggi Islam tersebut. Disekitar perguruan tinggi ini sebenarnya telah berdiri juga perguruan tinggi umum yang tidak kalah besar dan ternama di Nusa tenggara Barat. Tujuan dari penelitian ini adalah untuk mengetahui dan mendeskripsikan sejarah singkat Yayasan, konsep pengembangan dan perannya terhadap perkembangan pendidikan Islam. Metode yang digunakan adalah pendekatan kualitatif deskriptif, dengan bantuan beberapa analisisnya, menggunakan pendekatan Kuantitatif sambil teknik pengumpulannya datang melalui observasi, wawancara, bentuk pertanyaan dan dokumentasi. Hasil penelitian menunjukkan bahwa perguruan tinggi Nahdlatul Wathan Mataram Nusa Tenggara Barat didirikan tidak hanya untuk orang-orang Nahdlatul Wathan atau Islam tetapi yang lebih penting adalah untuk para dhuafah, orang miskin dan untuk orang-orang dari semua orang di Nusa Tenggara Barat untuk dapat turut andil dalam memajukan pendidikan di daerah tersebut. Pendiriannya dengan konsep rahmatan lil aalamin dan konsep organisme yang mengacu pada qur'an dan hadis, serta konsensus. Dan Perguruan Tinggi memiliki peran yang sangat mendesak terhadap perkembangan pendidikan Islam.
\end{abstract}

Keywords: Perguruan tinggi Islam dan pendidikan Islam.

\section{Pendahuluan}

Proses pendidikan, sebenarnya telah berlangsung sepanjang sejarah dan berkembang sejalan dengan perkembangan sosial budaya manusia di permukaan bumi. Khusus pendidikan Islam, berlangsung sejak agama Islam itu sendiri didakwahkan oleh Nabi Muhammad saw. Pendidikan Islam yang berlangsung di 
zaman Nabi Muhammad saw. dan beliau juga bertindak sebagai guru sekaligus pendidik utama ketika itu telah mengalami perkembangan yang cukup signifikan. Sepeninggal Nabi Muhammad saw. pendidikan Islam semakin berkembang seiring dengan semakin meluasnya wilayah Islam ke seluruh penjuru, termasuk di pulaupulau Indonesia.

Perguruan Tinggi Universitas Nahdlatul Wathan Mataram di Nusa Tenggara Barat Berdiri pada tahun 1990. Diketahui bahwa dalam sense sejarah dan Nahdlatul Wathan Mataram di Nusa Tenggara Barat masih terus berusaha meningkatkan kualitas pendidikannya untuk dapat mencetak lulusan-lulusan yang berkompetensi pada bidangnya. Universitas ini telah berusaha professional untuk memberikan kontribusi signifikan dalam pembaruan dan pengembangan pendidikan umum maupun Islam di Nusa Tenggara Barat.

Perguruan Tinggi Universitas Nahdlatul Wathan Mataram adalah salah satu Perguruan Tinggi Islam di Wilayah Nusa Tenggara Barat. Kehadiranya dapat memberika kontrubisi untuk pengembangan pendidikan Islam, salah satu bentuk kontribusinya adalah menghasilkan lulusan-lusan yang berlandaskan pada agama dan sebagian dari lulusan tersebut turut andil menjadi guru Pendidikan Agama Islam yang tersebar di beberapa instansi pendidikan di Nusa Tenggara Barat. Perguruan Tinggi Islam tersebut tidak hanya diminati oleh umat muslim saja akan tetapi yang lebih menarik adalah umat non-muslim juga tertarik untuk masuk ke Perguruan Tinggi Islam tersebut dengan perbandingan mahasiswa non-muslim sebanyak $30 \%$ sedangkan yang muslim sebanyak $70 \%$, padahal disekitar perguruan tinggi Islam tersebut telah banyak perguruan tinggi umum yang juga tidak kalah besar dan terkenal di Nusa Tenggara Barat.

Hal inilah yang membuktikan bahwa perguruan tinggi Islam tersebut adalah benar-benar perguruan tinggi yang dapat memberikan rahmatan lil'aalamiin kepada semua umat dan perlu dijadikan contoh tauladan bagi perguruan tinggi Islam maupun perguruan tinggi umum lainnya. Melihat dari perkembangan dan capaian perguruan tinggi ini maka perlu dilakukan penelitian untuk menggali lebih dalam tentang pergurun tinggi Universitas Nahdlatul Wathan Mataram sehingga dapat diketahui hal-hal yang perlu diperbaiki dan ditingkatkan untuk kemajuan pergurun tinggi Universitas Nahdlatul Wathan Mataram dan dapat memotivasi 
munculnya perguruan tinggi islam yang lebih maju kedepannya di Nusa Tenggara Barat dan di Kota Mataram pada khususnya.

Berdasarkan uraian diatas diketahui bahwa penelitian ini bertujuan: 1) Menelusuri profil dan sejarah latar belakang Perguruan Tinggi Universitas Nahdlatul Wathan Mataram dalam upaya pengembangan pendidikan Islam di Nusa Tenggara Barat dan di Kota Mataram pada khususnya. 2). Untuk mengetahui dengan jelas konsep pengembangan yang ditekankan Perguruan Tinggi Universitas Nahdlatul Wathan Mataram terhadap pengembangan Pendidikan Islam. 3). Mengungkap Peran Perguruan Tinggi Universitas Nahdlatul Wathan Mataram terhadap kontribusi pengembangan pendidikan Islam.

\section{Kajian Teori}

1. Pendidikan Islam

Istilah pendidikan dalam bahasa Yunani, adalah paedagogie, terdiri atas dua suku kata, yakni paes dan ago (Abu Ahmadi, 2009:69).Dari kata ini, dipahami bahwa pendidikan merupakan kegiatan belajar mengajar, dan unsur-unsur terpenting di dalamnya adalah sistem pendidikan, tujuan pendidikan, materi pendidikan, sistem pendidikan sarana dan prasarana pendidikan, cara penilaian dalam pendidikan dan seterusnya.

Untuk lebih memahami bagaimana pendidikan Islam tersebut, maka berikut ini dikemukakan beberapa definisi :

a. Muhammad Athiyah al-Abrāsy secara singkat menyatakan, pendidikan Islam adalah mempersiapkan individu agar ia dapat hidup dengan kehidupan yang sempurna (Muhammad Athiyah al-Abrāsy, 2006: 48).

b. Yusuf al-Qardawi menyatakan pendidikan Islam adalah sebagai pendidikan manusia seutuhnya, akal dan hatinya, rohani dan jasmaniyah, akhlak dan keterampilannya, dan menyiapkan untuk menghadapi masyarakat dengan segala kebaikan dan kejahatannya, manis dan pahitnya (Bustani A.Gani dan Zainal Ahmad, 2008: 39).

c. Hasan Langgulung menyatakan, pendidikan Islam adalah sebagai proses penyiapan generasi muda untuk menjadi peranan, memindahkan pengetahuan 
dan nilai-nilai Islam yang diselaraskan dengan fungsi manusia untuk beramal

di dunia dan memetik hasilnya di akhirat (Hasan Langgulung, 1990: 94).

Cukup dengan mengutip ketiga definisi yang disebutkan, dapat dirumuskan bahwa pendidikan Islam merupakan proses pembentukan individu berdasarkan ajaran-ajaran Islam. Melalui proses pendidikan itu, individu dibentuk agar dapat mencapai derajat yang tinggi dan sempurna (insan kamil).

\section{Konsep Pengembangan Pendidikan Islam}

Terdapat tiga konsep dan paradigma pengembangan pendidikan Islam, sebagai berikut

\section{a. Konsep Formisme}

Dalam konteks pendidikan Islam, masih ditemukan pe-mahaman paradigma formisme yang memandang adanya dikotomi atau diskrit. Segala sesuatunya dilihat dari dua sisi yang berlawanan, seperti laki-laki dan perempuan, ada dan tidak ada, bulat dan tidak bulat, madrasah dan non madrasah, pendidikan agama dan pendidikan umum, demikian seterusnya. Pandangan yang dikotomis tersebut pada giliran selanjutnya mengalami pengembangan dalam melihat dan memandang aspek kehidupan dunia, dan akhirat, kehidupan jasmani dan rohani sehingga pendidikan Islam hanya diletakkan pada aspek kehidupan akhirat saja atau kehidupan rohani saja. Dengan demikian, pendidikan keagamaan dihadapkan dengan pendidikan non-keagamaan, pendidikan keislaman dan nos-keislaman, pendidikan agama dan pendidikan umum. Karena itu, pengembangan pendidikan Islam hanya berkisar pada aspek kehidupan ukhrawi yang terpisah dengan kehidupan duniawi, atau aspek kehidupan rohani yang terpisah dengan kehidupan jasmani (Muhaimin, 2009: 39-40). Pandangan dikotomis inilah yang menimbulkan dualisme dalam sistem pendidikan. Istilah pendidikan agama dan pendidikan umum, atau ilmu agama dan ilmu umum sebenarnya muncul dari paradigma formisme tersebut.

Menurut penulis, ilmu apapun namanya, jika ia diletakkan dalam wadah yang islami, maka ilmu tersebut adalah "ilmu Islam” dan di luar itu tidak islami. Kalaupun memang sudah terlanjur ada pencaplokan bahwa ilmu-ilmu semisal fisika, ilmu sosial, ilmu bumaniora, dan selainnya merupakan "ilmu Barat", maka sebagai solusinya diperlukan pengembangan rumusan yang mapan tentang 
islamisasi sains. Islamisasi sains diinterprerasikan sebagai integrasi ilmu dengan wahyu, yakni memformat segala jenis ilmu pengetahuan berdasarkan nilai-nilai Islam. Karena itu, islamisasi sains, juga diterminologikan sebagai islamisasi ilmu pengetahuan yang dalam implementasinya menghilangkan konsep-konsep sekuler yang tidak islami di setiap persoalan yang berkaitan dengan pendidikan.

\section{b. Konsep Mekanisme}

Selain konsep formisme yang telah dijelaskan secara luas, ditemukan pula adanya paradigma mekanisme. Dalam aspek ini, paradigma mekanisme dalam pendidikan dipandang sebagai pengembangan seperangkat nilai kehidupan (Muhaimin, 2009: 39-40) Aspek-aspek atau nilai-nilai kehidupan itu sendiri, terdiri atas nilai agama, nilai individu, nilai sosial, nilai rasional dan lain-lain.

Dalam perspektif pendidikan Islam, umat Islam dididik dengan seperangkat ilmu pengetahuan atau mata pelajaran, salah satunya adalah mata pelajaran pendidikan agama yang mempunyai fungsi tersendiri, yaitu sebagai (1) pengembangan dan peningkatan keimanan dan ketaqwaan; (2) penyaluran bakat dan minat dalam mendalami agama; (3) perbaikan kesalahan, kekurangan dan kesalahan dalam keyakinan; (4) pencegahan hal-hal negatif dari lingkungannya atau budaya asing yang berbahaya; (5) sumber nilai atau pedoman hidup untuk mencapai kebahagiaan dunia dan akhirat; (6) pengajaran atau penyampaian pengetahuan keagamaan (Muhaimin, 2009: 39-40). Jadi pendidikan agama lebih menonjolkan fungsi moral dan spiritual, atau dimensi efektif daripada kognitif dan psikomotor, dalam arti dimensi kognitif dan psikomotor diarahkan untuk pembinaan efektif (moral dan spiritual), yang berbeda dengan mata pelajaran lainnya.

Sebagai implikasinya, pengembangan pendidikan Islam dalam arti pendidikan agama tersebut bergantung pada kemauan dan kemampuan dari para pembinanya dan sekaligus pimpinan dari lembaga pendidikan tersebut, terutama dalam membangun hubungan kerjasama dengan mata pelajaran (kuliah) lainnya. Hubungan (relasi) antara pendidikan agama dengan beberapa mata pelajaran atau mata kuliah lainnya dapat bersifat horizontal-lateral (independent), lateral-sekuensial, atau bahkan vertikal linier.Relasi yang bersifat horizontal-lateral (independent) mengandung arti bahwa beberapa mata pelajaran (mata kuliah) yang ada dan pendidikan agama 
mempunyai hubungan sederajat yang independent, dan tidak harus saling berkonsultasi. Relasi yang bersifat lateral skuensial, berarti di antara masing-masing mata pelajaran (mata kuliah) tersebut mempunyai relasi sederajat yang saling berkonsultasi. Sedangkan relasi vertikal-linier berarti mendudukkan pendidikan agama sebagai sumber nilai atau sumber konsultasi, sementara seperangkat mata pelajaran (mata kuliah) yang lain adalah termasuk pengembangan nilai-nilai insani yang mempunyai relasi vertikal-linier dengan agama.

\section{Konsep Organisme}

Konsep organisme yang bertolak dari pandangan bahwa pendidikan Islam adalah kesatuan atau sebagai sistem yang terdiri atas komponen-komponen yang rumit, yang berusaha mengembang-kan pandangan semangat hidup, yang dimanifestasikan dalam sikap hidup dan keterampilan hidup yang Islami (Muhaimin, 2009: 39-40). Dalam konteks pandangan semacam itu, pengembangan pendidikan Islam harus sesuai dengan doktrin Alquran dan sunnah sebagai sumber pokok kemudian mau menerima kontribusi pemikiran dari para ahli serta mempertimbangkan konteks historisitasnya.

Karena itu, nilai Ilahi (agama) didudukkan sebagai sumber konsultasi yang bijak, sementara aspek-aspek kehidupan lainnya didudukkan sebagai nilai-nilai insani yang mempunyai relasi horizontal-lateral atau lateral-sekuensial, tetapi harus berhubungan vertikal-linier dengan Ilahi (agama). Melalui upaya itu, maka sistem pendidikan Islam diharapkan dapat mengintegrasikan nilai-nilai ilmu pengetahuan, nilai-nilai agama dan etik, serta mampu melahirkan manusia-manusia yang menguasai ilmu pengetahuan dan teknologi, memiliki kematangan profesional, dan sekaligus hidup di dalam nilai-nilai agama. Model paradigma pengembangan pendidikan yang disebutkan ini, nampaknya mulai dikembangkan di madrasah.

\section{Metode Penelitian}

Pendekatan yang digunakan adalah pendekatan deskriptif kualitatif, karena penelitian ini berusaha untuk mendeskripsikan dan menganalisis fenomena, aktivitas sosial, sikap seseorang atau kelompok.Penelitian kualitatif adalah prosedur penelitian 
yang menghasilkan data deskriptif berupa kata-kata tertulis atau lisan dari orangorang dan perilaku yang dapat diamati (Bogdan dan Tylor dalam Zuriah, 2007:92).

\section{Prosedur Penelitian}

Prosedur pada penelitian penulis menggunakan system prosedur penelitian yang sederhana dengan melalui beberapa tahapan yakni tahapan pertama melakukan pengamatan/observasi secara langsung dilapangan dengan tujuan untuk mendapatkan mengidentifikasi masalah-masalah yang dapat dijadikan salah satu bahan untuk dapat menyusun tema, tahapan selanjutnya adalah merumuskan masalah masalah inti, studi kepustakaan dan menyusun metode rencana kerja. Tahapan selanjutnya adalah tahapan pengumpulan data, dengan melalui beberapa teknik pengumpulan data yakni observasi atau pengamatan lebih lanjut pada lapangan, melakukan wawancara baik secara langsung maupun tidak langsung dengan informan, serta memelusuri dokumen-dokumen terkait yang akan dikaji melalui forum diskusi sejawat. Tahapan berikutnya adalah mengelola data dengan cara menganalisis data, mengkolaborasikan hasil observasi, wawancara dan dokumentasi serta melakukan uji keabsahan data. apabila data-data yang ditemukan tersebut tidak valid maka langkah selanjutnya adalah kembali kepada tahapan awal. Setelah data-data dapat dianggap absah dan valid maka tahapan selanjutnya adalah pelaporan.

\section{Teknik Pengumpulan Data}

Mengumpulkan data dalam suatu penelitian di lapangan adalah salah satu langkah yang sangat fital. Secara umum teknik pengumpulan data banyak sekali caranya, seperti yang dikemukakan oleh Suharsimi Arikunto, bahwa teknik pengumpulan data itu bisa berupa ; (1) menggunakan tes; (2) menggunakan kuesioner/angket; (3) menggunakan metode interview; (4) menggunakan metode observasi; (5) menggunakan metode dokumentasi. Dari sekian metode tersebut, maka yang penulis gunakan dalam penelitian ini adalah mengunakan beberapa teknik pengumpulan data melalui observasi, wawancara dan dokumen

\section{Analisis Data}

Imron dalam Zuriah (2009), analisis data dalam penelitian kualitatif adalah proses pelacakan dan pengaturan secara sistematis transkrip wawancara, catatan lapangan, dan bahan-bahan lain yang dikumpulkan untuk meningkatkan 
pemahaman terhadap bahan-bahan tersebut agar dapat diinterpretasikan temuannya kepada orang lain. Dalam hal ini peneliti melakukan pencatatan pada saat wanwancara, mengumpulkan data-data dari dokumen yang relevan dengan penelitian berupa tulisan-tulisan hasil wawancara dengan Mahasiswa yang bersangkutan, hingga kegiatan selanjutnya yaitu menyusun hasil-hasil wawancara kemudian diketik dan dikembangkan untuk dianalisis sehingga menghasilkan sebuah kesimpulan. Sedangkan observasi dilakukan pada saat peneliti melakukan wawancara, peneliti terlibat langsung dilokasi kemudian mengamati kejadian kejadian di lapangan. Selain dari menggunakan analisis yang bersifat kualitatif penelitian ini dibantu dengan menggunakan teknik analisis kuantitatif dengan bantuan rumus persentasi, penggunakan rumus tersebut untuk mengetahui dan mengganalisis hasil angket yang telah disebarkan kepada masyarakat di Kota Mataram.

\section{Hasil dan Pembahasan}

\section{Konsep Pengembangan Pendidikan Islam}

Islam sebagai system nilai universal dan diyakini mutlak kebenarannya seharusnya memberikan paradigm filosofis dan teologi terhadap pendidikan Islam itu sendiri. Tetapi sayangnya pengertian pendidikan Islam yang berkembang dalam masyarakat baru sekedar menerapkan etika Islam dalam pemanfaatannya atau lebih sederhana lagi sebagai sebuah nama dari lembaga pendidikan yang dikelola oleh kaum muslimin. Padahal yang namanya pendidikan Islam seharusnya mengejewantakan nilai-nilai Islam dalam pendidikan baik secara ontology, epistemology dan aksiologisnya (Tobroni: 2008: 13).

Pendapat ini sejalan dengan sebagian temuan penulis menemukan bahwa sebagian dari para pengelola Perguruan Tinggi Islam masih ada yang belum paham tentang konsep pendidikan islam yang sebenarnya sehingga dalam pelaksanaannya hanya pada sebatas pengetahuan sementara pada tataran implementasinya masih kurang. Hal ini dapat diperhatikan secara bersama, apabila para pemimpin atau penglola Perguruan Tinggi Islam memahami pendidikan islam secara implisit pasti dalam suasana proses kegiatan belajar mengajar minimal dapat mengejewantakan nilai-nilai islam kedalam kegiatan 
tersebut, akan tetapi kebanyak sebagian pengelola bahkan para pendidikan terutama pendidikan non kependidikan Islam, kurang memperhatikan nilainilai pendidikan islam yang terkandung dalam proses belajar mengajarnya.

Tedi Priatna (2004: 1-5) yang dikutip oleh Beni Ahmad Saebani berpendapat bahwa memahami pendidikan Islam tidak semudah menguraikan kata "Islam" dari kata "pendidikan" karena selain sebagai predikat, Islam merupakan satu subtansi dan subjek penting yang cukup kompleks. Oleh karena itu untuk memahami pendidikan Islam perlu melihat aspek utama misi agama Islam yang diturunkan kepada umat manusia secara pedagogis. Islam sebagai ajaran yang dating dari allah yang merefleksikan nilai-nilai pendidikan yang mampu membimbing dan mengarahkan manusia sehingga menjadi manusia sempurna. Islam sebagai agama universal telah memberikan pedoman hidup bagi manusia menuju kehidupan bahagia, yang capaiannya bergantung pada pendidikan (Beni Ahmad Saebani, dkk: 2009).

Pembaharuan dalam dunia Islam sudah dimulai oleh tokoh cendekiawana Islam seperti Ibnu Taimiyah, Al-afghani, Muhammad abduh, Rasyid Ridha, Fajlur Rahman dan pemikir lainnya. Buah pemikiran tokohtokoh Islam ini mempunyai pengaruh besar pada perubahan pola pendidikan Islam dan cara pengalamannya. Memperbarui pemahaman keagamaan (keIslaman) yang masih bersifat ortodoks/kolot dan dikotomis.Paling tidak para cendekiawan tersebut sebagia salah satu contoh bagi para pendidik untuk dapat diikuti jejaknya.

Sejalan dengan pendapat Ahmad Tafsir (2006:32), menyatakan bahwa:"Pendidikan Islam sebagai bimbingan yang diberikan oleh seseorang agar ia berkembang secara maksimal sesuai dengan ajaran Islam atau dengan kata lain pendidikan Islam adalah bimbingan terhadap seseorang agar ia menjadi seorang muslim semaksimal mungkin". Ahmad tafsir (2006: 32) menekan pada sifat dari aktifitas pendidikan Islam yaitu berupa bimbingan sebagai suatu upaya yang tidak hanya ditekankan kepada aspek pengajaran/transfer ilmu pengetahuan, tetapi berupa arahan, bimbingan, pemberian petunjuk dan pelatihan menuju terbentuknya pribadi muslim yang seutuhnya". 
Hemat penulis, pendidikan Islam sangatlah urgen dalam dunia pendidikan, karena melalui pendidikan Islam seseorang yang belum mendapatkan petunjuk untuk mengapai tujuan hidupnya sebagai hamba Allah yang hanya untuk beribadah kepadanya dapat terpenuhi. Dan dalam menjalankan tugasnya sebagai khalifah di muka bumi baik ia sebagai pendidik, non kependidikan dan apapun jenis profesinya dapat dijalankan dengan baik sesuai yang digariskan dalam petunjuk yang telah dititipkan yaitu al-qur'an dan hadits.

Pemikiran Fazlur Rahman (1919) yang menyuguhkan analisis perkembangan pendidikan Islam dan merumuskan alternative metodologi pemikiran keIslaman sebagai rumusan jalan keluar dari seluruh kritisisme atas sejarah pemikiran keIslaman yang cenderung konservatif untuk memujudkan masyarakat Islam sebagai competitor dipentas global memerlukan sarana penunjang yaitu perubahan pada system kelembagaan pendidikan Islam. sistem pendidikan Islam terlebih dahulu harus dimodernisasi atau diperbaharui.

Fazlur rahma meniscayakan bahwa rakyat di negara Islam mempunyai kekuasaan untuk menerjemahkan teks al-qur'an guna merancang undang-undang untuk kemaslahatan umatnya. Kedaulatan allah dalam kiblatnya tidak bisa dipandang sebagai sesuatu yang absolut atau kaku. Sebab dalam al-qur'an memiliki konsekwensi berupa perlunya suatu kerangka pembaharuan dalam rangka mengungkapkan ajaranajaran moral yang ada didalamnya

Konsep pendidikan Islam yang diperankan Perguruan Tinggi Universitas Nahdlatul Wathan Mataram memang sejalan dengan pendapat fazlur Rahman, karena Perguruan Tinggi Universitas Nahdlatul Wathan Mataram selalu merujuk dan mengkaji al-qur'an dan hadits serta menjadikan ijtihad para ulama sebagai dasar pijakan penetapan dan pengambilan keputusan pada setiap masalah yang sedang dihadapinya. Salah satu contoh yang dilakukan adalah mengembangkan pendidikan Islam melalui dakwah, pembinan dan pengajaran, penelitian dan pengabdian pada masyarakat,meningkatkan kerjamasa dengan instansi-instansi pemerintah dan setiap komponen-komponen yang dilakukan tersebut tidak terlepas dari sumber utama yaitu al-qur'an dan hadits.

Dengan memperhatikan konsep ini, hemat penulis bahwa Perguruan Tinggi Universitas Nahdlatul Wathan Mataram memahami konsep pengembangan 
pendidikan Islamnya dengan konsep organisme, konsep organisme yang dimaksud adalah memandang bahwa pendidikan Islam adalah satu kesatuan atau sebagai system yang terdiri atas komponen-komponen yang rumit, yang berusaha mengembangkan padangan semangat hidup, yang dimanifestasikan dalam sikap hidup dan ketermpilan hidup yang Islam (Muhaimin: 2009: 39-40) dalam konteks pandangan tersebut pengembangan pendidikan Islam harus sesuai dengan doktrin al-qur'an dan hadits sebagai sumber pokok, kemudian menerima kontribsi pemikiran para ahli serta mempertimbangkan konteks historisnya, karena itu nilai ilahi didudukan sebagai sumber konsultasi yang bijak, sementara aspek-aspek kehidupan lainnya didudukan sebagai nilai-nilai insani yang mempunyai relasi horizontal-latera/lateral-sekunsial tetap harus berhubungan dengan vertical-linear dengan ilahi/agama.

Selain mengembangkan konsep organisme, konsep lain yang seirama juga perlu diperhatikan oleh Perguruan Tinggi Islam dalam mengembangankan pendidikan Islam. hemat penulis Perguruan Tinggi Islam perlu memprioritaskan konsep pengembangan pendidikan Islam modern salah satu konsep yang ditawarkan adalah reorentasi pendidikan Islam modern, sebagaimana yang dikutip Ikhlas (2015) dalam jurnal ilmiah kreatif; beberapa point tentang pengembangan pendidikan Islam modern diantaranya reorentasi pendidikan Islam dengan kutipan pendapat Malik Fadjar menyampaikan kritik kepada pendidikan yang diterapkan oleh lembaga pendidikan Islam seperti pondok pesantren yang monoton pada agama dan sangat berbeda dengan model sekolah Negara haruslah dirubah dengan system pendidikan terpadu, yakni memadukan ilmu agama dengan system pendidikan umum. Dengan demikian lembaga pendidikan Islam akan menghasilkan output yang matang dalam agama dan memiliki semangat patriotisme (Malik Fadjar; 2006:24).

Begitu juga dengan Perguruan Tinggi harus menerapkan pola Perguruan Tinggi yang mengabungkan antara pola Perguruan Tinggi umum dan Islam dengan mengadopsi pendidikan model barat, karena system dipandang terbaik dan disempurnakan dengan penambahan mata kuliah krearifan local (local wisdom) dengan mengIslamkan berbagai segi kehidupan yang tidak Islami. Agama Islam tidak diarahkan kepada pemahaman mistis melainkan menghadapi dunia secara realistis. Salah satu sarana yang untuk melakukan upaya pembaharuan atau mereorintasi pendidikan dapat menjadikan Nahdlatul Wathan dan nahdatul ulama (NU) sebagai 
objek kajiannya khusus pada oreantasi wawasan pendidikan Islam di Indonesia, sebab kedua organisasi tersebut merupakan ormas Islam terbesar di Indonesia dan cukup representative untuk dijadikan bahan analisis dalam kerangka pembaharuan pendidikan yang ada dinegeri ini.

Malik Fadjar yang dikutip Ikhlas mengatakan bahwa beberapa gagasan reoreantasi serta rancangan pendidikan Islam agar ada perubahan yang berarti dimasa depan dalam rangka mewujudkan pendidikan Islam yang bermartabat untuk perubahan hidup yang berkarakter melalui pola pendidikan diantarannya adalah:

\section{a. Menjadikan Islam sebagai acuan cita ideal}

Islam harus dijadikan sebagai acuan cita ideal pendidikan Islam sekalipun kedua gerakan Islam Nahdlatul Wathan dan NU tidak secara implisit menyebutkan Islam sebagai bagian dari namanya, namun semua tahu bahwa keduanya berstatus sebagai organisasi masa Islam serta berperan sebagai gerakan social keagamaan yang beraqidah Islam. hal ini tercermin dalam tujuannya "menegakkan dan menjunjung Tinggi Agama Islam, sehingga terwujud masyarakat utama, adil, makmur dan diridhoi Allah SWT.

Dari rumusan tujuan tersebut kedua organisasi Islam menempatkan Islam sebagai acuan cita idealnya, yang tidak mungkin digangu gugat. Pendidikan yang bernaung dibawah panji kedua organisasi tersebut bukan semata-mata untuk membantu menumbuhkan lapisan mobilitas antar lapisan umat Islam atau masyarakat yang lebih luas, namun sekaligus sebagai cagar yang menjamin terselamatkannya struktur dan indentitas dari generasi.Cristoper J.Lucas menyatakan pendidikan adalah markas penyimpan kekuatan luar biasa, yakni memiliki akses keseluruhan aspek kehidupan, memberi informasi yang paling berharga mengenai pegangan hidup masa depan serta membantu generasi dalam mempersiapkan kebutuhan esensialnya untuk menghadapi perubahan (Ikhlas: 2015: 201-203).

\section{b. Berorientasi Kualitas bukan Populis}

Untuk melakukan reoreantasi pada lembaga pendidikan Islam perlu diarahkan pada pemberian ruang gerak yang seluas-luasnya pada fungsi esensial dari pendidikan. Dalam arti pelaksanaan pendidikan bukan pada asas kepentingan mendapatkan popularitas di tengah masyarakat tetapi yang jauh lebih penting dari 
itu adalah bagimana roh pendidikan dapat diinternalisasikan dalam diri insan akademik sehingga memiliki kualitas excellent yang dapat bersaing dikanca local, nasional dan internasional. Sederhananya pendidikan bukan berbicara kwantitas akan tetapi yang paling penting adalah kualitas yang dimilikinya, karena pendidikan yang diselenggarakan selama ini kebanyakan lebih kepada pemenuhan kebutuhan tanpa harus memikirkan output pada lembaga pendidikan tersebut. Sebagai bahan studi kajian, ormas terbesar di Indonesia NU dan Nahdlatul Wathan yang sudah mendapatkan pengakuan public (Public Trust) harus mampu meningkatkan kualitas pelaksanaan pendidikan, baik dari segi kurikulum, manajemen pengelolaan, sarana dan prasarana yang mendukung kelancaran kegiatan pendidikan. Dengan demikian pendidikan Nahdlatul Wathan dan NU tidak sekedar menikmati pengakuan peran kuantitatif dari masyarakat dan pemerintahan, akan tetapi lebih menghasilkan generasi yang berkualitas untuk menembus nobel tingkat internasional.

\section{c. Pendidikan Islam Perlu Pilot Project}

Perguruan Tinggi Islam seperti Perguruan Tinggi Nahdlatul Wathan maupun Perguruan Tinggi umum lainnya harus mampu membuat atau merancang sebuah pilot project yang handal secara spiritual Islami, berwawasan keilmuan dan empirik khusus yang pendidikan tinggi Islam dan spiritual keagamaana khusus pendidikan tinggi umum lainnya, sehingga bisa melahirkan hasil yang hatinya dilimpahi suasana iman, dan dalam pikiranya dilimpahi ilmu pengetahuan serta ditangannya tersimpan sejuta kecakapan. Tanpannya piloc project semacam ini mendapat dukungan dari berbagai pihak, apalagi kondisi politik dan perekonomian pendukungnya sangat memungkinkannya, namun untuk merealisasikannya perlu persiapan yang benar-benar matang, terutama jika pilot project berskala internasional seperti yang dilakukan oleh Muhammad Naquib Al-Attas melalui ISTC di Malaysia membuat sebuah lembaga pendidikan yang memiliki haluan Islam modern yang didukung oleh kalangan cendekiawan Muslim dan pemerintah setempat.

Dengan jumlah pendidikan Islam yang diselengarakan oleh Nahdlatul Wathan dan NU yang begitu besar, sebelum memulai pilot project perlu assessmen, hasilnya disebut feasibility study, mendesain perencanaan serta melakukan perencanaan dengan persiapan yang matang. sebagai langkah awal bisa dilaksanakan pada Perguruan 
Tinggi Islam yang bernaung dibawah Nahdlatul Wathan dan Nahdatul Ulama. Dalam pelaksanaan pilot project selain mempersiapkan biaya yang cukup, keberanian dan terbebas dari ikatan-ikatan formalitas yang bersifat birokrat seperti penghargaan dan pengakuan perlu di hindari oleh Perguruan Tinggi tersebut. Karena tersebut dapat menganngu konsentrasi visi, misi dan tujuan pilot project yang sedang dirancang/dilaksanakan.

\section{Peran Perguruan Tinggi Terhadap Pengembangan Pendidikan Islam}

Berdasarkan hasil penelitian bahwa Perguruan Tinggi Universitas Nahdlatul Wathan Mataram adalah salah satu Perguruan Tinggi Islam yang memiliki peran yang sangat urgen dalam mengembangakna pendidikan Islam di Nusa Tenggara Barat. Dengan menujukan beberapa peran nyata yang dilakukan oleh Perguruan Tinggi Universitas Nahdlatul Wathan Mataram, maka perguruan tersebut harus meningkatkan kualitas dan kuantitas terhadap pengembangan pendidikan Islam.

Beberapa peran yang dilakukan oleh Perguruan Tinggi Universitas Nahdlatul Wathan Mataram dalam mengembangan pendidikan Islam antara lain adalah meningkatkan kualitas dakwah amal ma'ruf nahi munkar, meningkatkan kualitas pembinaan dan pengajaran, kualitas penelitian dan pengabdian masyarakat, meningkatkan kualitas dan kuantitas kerjasama dibidang agama, politik, ekonomi dan lainnya. Dengan beberapa bentuk peran yang lakukan tersebut Perguruan Tinggi Universitas Nahdlatul Wathan Mataram harus terus mengembangkan inovasi dan kreatifitas dalam mengembangankan pendidikan Islam. salah satu peran yang harus dilakukan adalah meningkatkan kerjasama dengan pihak internal kampus seperti adanya kesamaan tujuan untuk mencapai visi, misi Perguruan Tinggi tersebut.

Apabila sudah tercapainya kesamaan untuk mencapai visi, misi Perguruan Tinggi tersebut maka apapun yang dilakukan dapat tercapai dengan sempurna. Berikut ini tugas yang harus dikembangankan oleh Perguruan Tinggi Universitas Nahdlatul Wathan Mataram adalah

\section{a. Pembinaan Karakter Secara Terpadu}

Untuk mencapai kesamaan pendapat dan pemahaman dalam mencapai visi, misi dan tujuan Perguruan Tinggi Islam perlu adanya pembinaan karakter secara terpadu yang harus dilakukan oleh pimpinan Perguruan Tinggi tersebut. 
Senada dengan pendapatnya Lickona (1991) yang dikutip Muhaimin dalam buku

Pengembangan Kurikulum Pendidikan Islam (2010: 59) mengatakan bahwa;

Untuk membina keimanan peserta didik diperlukan pengembangan ketigatiganya secara terpadu yaitu pertama moral knowing yang meliputi 1) Moral Awareness, 2) Knowing Moral values, 3) Perspective-taking, 4) Moral Reasoning, 5) Decision Making, 6) Self- Knowledge. Kedua Moral felling meliputi: 1) Conscience, 2) Self-esteem, 3) Empathy, 4) Loving the Good, 5) Self-Control, 6) Humality. Ketiga Moral Action meliputi: 1) competence, 2) Will, 3) Habit. Pada tataran Moral Action, agar peserta didik terbiasa (babit), memiliki kemauan (will) dan Kompeten (competence) dalam mewujudkan dan menjalankan nilai-nilai keimanan tersebut, maka diperlukan penciptaan suasana religious disekolah dan diluar sekolah. Hal ini sebabkan karena nilai-nilai keimanan melekat pada diri peserta didik kadang-kadang bias terkalahkan oleh godaan-godaan setan baik berupa jin dan manusia maupun budaya budaya negatif yang berkembang disekitarnya. Karena itu bisa peserta didik suatu hari sudah kompeten dalam menjalankan nilai-nilai keimanan tersebut, pada saat yang lain menjadi tidak kompeten lagi. Dalam sebuah hadis Nabi Saw dinyatakan bahwa "al-iman yazid wa yanqush" Iman itu bisa bertambah dan bisa berkurang (Muhaimin: 2010: 59-61).

Dengan memberikan pembinaan secara terpadu ketiga dimensi tersebut pemahaman keagamaan atau suasana keagamaan dapat tercipta dengan baik dilingkungan Perguruan Tinggi Islam, dan apabila telah dibangun pemahaman keagamaan yang sudah matang dalam setiap individu yang ada di Perguruan Tinggi tersebut maka semua tindakan termasuk untuk melakukan pengembangakan pendidikan agama Islam dimana saja meraka berada pasti bisa dilakukan walaupun dengan sebuah nasihat yang baik untuk mahasiswa dan masyarakat yang ada disekitarnya.Peran dosen dalam mengembangkan pendidikan Islam sangatlah penting dalam sebuah perguruan Islam karena dosen adalah salah satu sumberdaya manusia yang perlu di tingkatkan kualitasnya, sebab dari dosen tersebutlah, pendidikan Islam dapat berkembang, oleh karena itu, pimpinan Perguruan Tinggi harus benar-benar memikirkan kualitas para pendidik atau dosen yang ada dilingkungan perguruan tingginya. Sejalan dengan Pernyataan Anies Baswedan mengatakan bahwa:

"Kemajuan suatu bangsa terletak pada kualitas dari sumber daya manusia yang dimiliki negara tersebut. Berbicara mengenai kualitas sumber daya manusia berkaitan 
erat dengan pengembangan pembangunan pendidikan. Menteri Pendidikan dan Kebudayaan (Mendikbud) Anies Baswedan menyampaikan tiga strategi pengembangan pendidikan saat diwawancarai Tempo TV, di kantor Kementerian Pendidikan dan Kebudayaan (Kemendikbud), Rabu (31/12/2014). "Bila tiga strategi ini dapat dijalankan dengan baik, maka akan tercipta ekosistem yang baik dalam dunia pendidikan, ketiga strategis tersebut adalah 1) Pengembangan Guru/Dosen, 2) Memperkuat peran dan kerjasama orangtua dan masyarakat, 3). Melibatkan para siswa (mahasiswa) sebagai upaya menciptakan suasana yang menyenangkan dalam proses belajar mengajar " ucap(http/www.Seno Hartono.go.id).

\section{b. Menciptakan suasana Religious pada Lingkungan Perguruan Tinggi}

Perguruan Tinggi Islam adalah salah satu Perguruan Tinggi yang selalu bernaung dan berpedoman pada al-qur'an dan hadits, sehingga setiap keputusan dan tindakan yang diambil harus berdasarkan pada al-qur'an dan hadits. Kenyataana ini seharus dilakukan oleh semua Perguruan Tinggi Islam maupun Perguruan Tinggi umum yang mayoritas pengelolahnya adalah umat muslim. Karena salah satu tujuan pendidikan adalah memanusiakan manusiamenjadi manusia yang terbaik dimata Allah, manusia dan alam semesta. Untuk menciptakan manusai yang terbaik perlu adanya pembinaan dan bimbingan pada peserta didik/mahasiswa secara kontinyu dan tersistem baik diluar kelas maupun didalam kelas dan perlu ada kerjasama yang baik antar mahasiswa/warga sekolah/kampus dan tenaga kependidikan yang ada didalamnya.

Senada dengan Pendapat Anies Baswedan sebut sejalan dengan pendapat Muhaimin (2010: 59) mengatakan bahwa: Untuk membentuk peserta didik menjadi manusia yang beriman dan bertakwa kepada tuhan yang maha esa serta berakhlak mulia ternyata tidak bias hanya mengandalkan pada mata pelajaran agama yang hanya 2 jam pelajaran atau 2 sks, tetapi perlu pembinaan secara terus menerus dan berkelanjutan diluar jam pendidikan agama, baik didalam kelas maupun diluar kelas atau diluar sekolah. Bahkan diperlukan kerjasama yang harmonis dan interaktif diantar warga sekolah dan para tenaga kependidikan yang ada didalamnya.Perguruan Tinggi Islam perlu memperhatikan hal tersebut, karena tanpa adanya penciptaan suasanana keagamaan dilingkungan Perguruan Tinggi maka Perguruan Tinggi tersebut dapat dikatakan tidak memberikan sumbangsih 
yang berharga bagi pengembangan pendidikan Islam untuk kejayaan Islam kedepan. Menciptakan suasana religus pada lingkungan Perguruan Tinggi berarti Perguruan Tinggi tersebut telah memberikan peran yang sangat berarti bagi pengembangan pendidikan Islam lebih-lebih pada lingkungan masyarakat Islam minoritas.

Pernyataan pakar pendidikan Islam tentang perlunya membentuk manusia yang beriman dan bertakwa serta berakhlak mulia tersebut perlu dilaksanakan oleh Perguruan Tinggi baik Perguruan Tinggi Islam maupun Perguruan Tinggi umum lainnya. Membentuk manusia yang beriman dan bertakwa serta berakhlak mulia khususnya pada program studi pendidikan umum lainnya tidak cukup dengan mengandalkan mata kuliah pendidikan agama Islam yang hanya 2 sks. Akan tetapi yang perlu diperhatikan adalah pembinaan keagamaan yang secara berkelanjutan perlu diperhatikan oleh pimpinan Perguruan Tinggi tersebut sehingga terciptanya suasana religus dalam lingkungan Perguruan Tinggi yang dimilikinya.

\section{c. Islamisasi Ilmu Pendidikan}

Berdasarkan hasil penelitian penulis menemukan bahwa Perguruan Tinggi Universitas Nahdlatul Wathan Mataram melakukan tahapan awal untuk memperkenalkan kepada seluruh mahasiswanya dalam memperlajari program Bahasa Arab dan Al-Islam KeNahdlatul Wathanan baik yang beragama Islam maupun yang non-muslim, dengan tujuan dan harap agar mahasiswa tersebut dapat mengenal dan mengetahui bahwa Bahasa Arab adalah salah satu bahasa pengantar internasional yang penting untuk dipelajari setelah bahasa inggris, disamping untuk memperkenalkan sebagai bahasa pengantar, bahasa arab adalah bahasa asli dalam kitab-kitab semua agama baik agama Islam maupun agama nonmuslim. Sedangkan untuk mata kuliah Al-Islam dan KeNahdlatul Wathan adalah salah satu mata kuliah wajib yang harus diprogramkan oleh siapa saja yang masuk di Perguruan Tinggi Nahdlatul Wathan dimanapun berada, karena mata kuliah tersebut adalah mata kuliah yang diamanahkan oleh Pimpinan Pusat Nahdlatul Wathan, hemat penulis melalui mata kuliah tersebut mahasiswa khususnya mahasiswa muslim agar dapat membekali dirinya dengan ilmu-ilmu pendidikan Islam sehingga mahasiswa tersebut tidak mudah melupakan Allah sebagai Tuhan yang Maha Kuasa yang telah menciptakannya. Sedangkan untuk mahasiswa non- 
muslim, hemat penulis agar meraka diperkenalkan bahwa agama Islam adalah agama yang rahmatallil aalamin, agama yang toleran bukan agama yang intoleran sebagaimana yang dipahami sebagaian orang bahwa Islam adalah agama yang intoleran.

Dengan hasil penelitian ini, penulis dapat menganalisiss bahwa Perguruan Tinggi Universitas Nahdlatul Wathan Mataram sudah berusaha mengIslamkan ilmu pendidikan umum kedalam pendidikan Islam atau Islamisasi ilmu pendidikan melalui pendidikan bahasa arab dan al-Islam dan keNahdlatul Wathanan, akan tetapi hal ini baru hanya sebatas memperkenalkan belum pada tataran implementasi secara nyata pada mata kuliah-mata kuliah pada program studi lainnya misalnya program studi biologi, bahasa, ekonomi, perikanan, social dan lainnya. Menurut hemat penulis apabila ilmu-ilmu tersebut dapat dikaitkan dengan ilmu Islam atau sebaliknya, teori-teori pada ilmu tersebut dikonfirmasikan pada al-qur'an dan hadis atau ijmah para ulama yang shahih, maka nyatalah Islamisasi ilmu atau sain Barat kedalam ilmu pendidikan Islam.

Salah satu tugas yang paling urgen Perguruan Tinggi Islam khususnya Perguruan Tinggi Universitas Nahdlatul Wathan Mataram yang memiliki sejumlah program studi umum adalah Islamisasi ilmu pendidikan, hemat penulis dengan mengIslamisasi ilmu-ilmu pendidikan barat kedalam ilmu pendidikan Islam suasana pengembangan pendidikan Islam dilingkungan Perguruan Tinggi tersebut akan terasa nyata pengembangan pendidikan Islamnya.Sebagai tawaran penulis untuk Perguruan Tinggi Islam dalam mengembangkan pendidikan Islam adalah ada dua cara untuk mengembangkan ilmu pendidikan Islami atau Islamisasi ilmu pendidikan, pertama; cara deduksi kita mulai dari teks wahyu/alqur'an atau sabda rasul, lantas ditafsirkan, dari sini muncul teori pendidikan pada tingkat filsafat;teori itu dieksperimenkan, dari sini akan muncul terori pendidikan pada tingkat ilmu (sain). Uraian lebih lengkap tentang proses membuat teori tersebut dapat dilihat pada buku epistemology untuk pengembangan ilmu pendidikan Islam (Tafsir: 1995: 96). Cara deduksi memang menjamin teori teori yang diproduksi tidak akan menyimpang dan berlawanan dengan ajaran Islam. tetapi cara ini amat lama, mahal dan sulit.Cara kedua adalah cara induksikonsultasi yaitu mengambil teori yang sudah ada baik dari barat maupun dari 
timur setelah itu dapat dikonsultasikan ke al-qur'an dan hadits, jika tidak berlawanan, maka teori tersebut dapat didaftarkan kedalam khazanah ilmu pendidikan Islami (Ahmad Tafsir:2010).

Jadi kesimpulannya bahwa Islamisasi ilmu pendidikan adalah salah satu tugas yang wajib dikembangkan oleh ilmuan-ilmuan Islam yang ada pada Perguruan Tinggi Islam karena dengan mengIslamisasi sain/ilmu pendidikan Barat kedalam Islam, maka para ilmuan muslim dapat menguasai atau paling tidak dapat bersaing dengan para pemikir dan pakar-pakar pendidikan dan non pendidikan barat yang sejak saat ini menguasai dunia, padahal apabila dilihat dari sejarah Islam telah menguasai dunia selama 15 abad baik dunia pendidikan maupun non pendidikan.

\section{d. Mengembangkan Fakultas Agama Islam}

Untuk mewujudkan pengembangan pendidikan Islam yang luas dan lebih nyata di Nusa Tenggara Barat, hal yang pertama yang harus dipikirkan oleh Pimpinan Universitas dan Fakultas adalah bagimana cara mengembangan Fakultas Agama Islam kearah yang lebih baik dan terarah. karena Fakultas Agama Islam adalah rohnya Universitas Universitas Nahdlatul Wathan Mataram. Oleh karena itu pengembangan dan peningkatan kualitas Al-Islam dan KeNahdlatul Wathanan dan bahasa arab harus benar-benar digenjot dengan serius. Apalagi dengan telah didukung dengan laboratorim bahasa yang sudah memadai, tinggal eksen dan kesungguhan para pimpinan yang diikuti oleh para dosen yang ada di Fakultas Agama Islam. Hemat penulis bahwa dengan meningkatkan kualitas al-Islam kemuhammmadiyahan dana bahasa arab di Perguruan Tinggi Universitas Nahdlatul Wathan Mataram, maka pengembangan pendidikan Islam kedepan di Nusa Tenggara Barat akan lebih nyata dan terpercaya.

Pertama-tama yang harus dilakukan adalah penetapan kesatuan visi, misi antara universitas dan FAI. Kedua, menjadikan wacana keilmuan dan keIslaman sebagai semboyang dalam proses implementasis tri darma Perguruan Tinggi.Ketiga, memberlakukan sentralisasi tanpa menumpuhkan kreativitas, universitas memberlakukan sentralisasi dalam beberapa kebijakan seperti keuangan, pembiayaan dan lain-lain untuk tercapainya efesiensi, namun memberikan keluasan kepada fakultas dalam mengembangkan akademik. Keempat, efektifitas dan efesiensi. Guna peningkatan efektifitas dan efisiensi diberlakukan peranan dan fungsi dosen, zero 
growth, dan kesejahteraannya. Kelima, transparansi dan responsibiltas. Dalam konteks ini Pimpinan Universitas dan Fakultas memberlakukan kebijakan terbuka. Perpustakaan pendirian lembaga penjaminan mutu.Keenam, menuju world class university. Untuk menuju WCU ini, universitas melakukan rekruitmen dosen dengan prestasi TOEFL yang memungkinkan dapat meraih beasiswa diluar negeri, bukan berdasarkan kedekatan hubungan keluarga dan suku. Membuka kelas internasional di FAI yaitu prodi PAI dan Magister Hukum Islam dengan pengantar Arab dan Bahasa Inggris. Menerima mahasiswa internasional dengan hasil MOU atau kerjasama dengan universitas LN (MoU dan LoI FAI dengan PT M'sia). Melakukan akselerasi presentasi dan penulisa artikel ilmiah diforum dan jurnal internasional (Amsal Bahktiar dan H.M Abdul Fattah Santoso: 2017: 53-55).

Disamping keenam upaya diatas dalam kegiatan penelitian dan pengabdian kepada masyarakat, Universitas Universitas Nahdlatul Wathan Mataram harus memberlakukan kebijakan pelibatan berbagai unsur mahasiswa dilibatkan melalui penelitian kolaboratif dan terlibat dalam kegiatan mahasiswa seperti kegiatan PKM. Dalam konteks ini pula, kemajuan-kemajuan yang dicapai oleh Perguruan Tinggi Nahdlatul Wathan lainnya dapat diarahkan berdampak pada kemajuan Persyarikatan, misalnya memfasilitas program PPM, PWM, PDM, PCM, PRM dan ortom-ortom dalam Nahdlatul Wathan. FAI berkerjasama dengan majelis tarjih dan majelis tablig PWM. Pelibatan sumber daya manusia (PTM) dalam kepengurusan dan kegiatan PPM, PWM, PDM, PCM, PRM, ortom-ortom dan integrasi program pengabdian kepada masyarakat (LPPM dan Lazizmu) dengan pemberdayaan C \& R.

\section{Kesimpulan}

Peran Perguruan Tinggi Islam terhadap pengembangan Pendidikan Islam sangatlah urgen pada abab ini, karena salah satu yang dapat menyelesaikan masalah dikotomi ilmu pengetahuan sain Barat dan Timur. Untuk menjawab permasalah tersebut minimal Perguruan Tinggi Islam dapat mengembangkan Fakultas Agama Islam lebih berkualitas, menghidupan suasana religious dilingkungan perguruan tinggi, mempertajam kajian dan analisis kitab-kitab klasik (Timur dan Barat), Islamisasi Ilmu pendidikan, memberikan bimbingan dan pembinaan secara terpadu kepada semua baik mahasiswa, tenaga pendidik, non pendidik, karyawan, Satpam, 
cleaning Servis, pengelola kanting dan semua yang terlibat didalamnya dan yang paling penting adalah segala sesuai yang harus dilandaskan pada rujukan yaitu alqur'an, hadits, dan ijma'.

\section{Daftar Pustaka}

Ahmad Tafsir, 2010, Filsafata Pendidikan Islam, Bandung PT Remaja Rosdakarya.

Ahmad Tafsir: 1995, Epistemologi Untuk Pendidikan Islam, Bandung: Fakultas Tarbiyah

IAIN Bandung.

Ahmad Tafsir: Ilmu Pendidikan Dalam Perspektif Islam Bandung PT Remaja Rosda Karya, 2006 Hlm 32)

Ahmadi, Abu ,Ilmu Pendidikan (Cet.I; Jakarta: Rineka cipta, 2009)

Al-Abrāsy, Muhammad Athiyah, Rüh al-Tarbiyah wa al-Ta'limm.

Al-Qardhawi, Yusuf.Pendidikan Islam dan Madrasah terjemahan Bustani A. Gani dan Ahmad, Zainal Ilmu Pendidikan (Jakarta: Bulan Bintang, 2008).

Al-Qur'an Terjemahan Kementerian Agama Islam Republik Indonesia.

Amalo, Syaiful, sambutan dalam pembekalan mahasiswa Prodi Akhwal Al-

Syakhsyiyah Unmuh Mataram praktek kegiatan Lapangan, 24 Februari 2016

Amsal Bahktiar dan H.M Abdul Fattah Santoso, 2017, Penguatan Tata Kelola Ptki

Swasta; Inovasi Kelembagaan Dan Manajemen, Jakarta: Direktorat Pendidikan Tinggi.

Arikunto, Suharsimi, 1993, Prosedur Penelitian; Suatu Pendekatan Praktek. Cet. IX;

Jakarta: Renika cipta.

Azra, Azyumardi, 2008, Esei-esei Intelektual Muslimdan Pendidikan Islam (Jakarta: Logos

Wacana Ilmu.

Beni Ahmad Saebani, dkk: 2009, Ilmu Pendidikan Islam,Bandung: Cv.Pustaka Setia.

Departemen Agama RI, 1992 Al-Qur'an dan Terjemahnya (Jakarta: Proyek Pengadaan

Kitab Suci Al-Qur'an. 
http/www.Seno Hartono.go.id Kemendikbud), Rabu, 31/12/2014 diakses tanggal 27 Juli 2017.

Ikhlas, 2015, Jurnal Ilmiah Kreatif, Volume XII Nomor 2 edisi Juli 2015 Ber-ISSN 0216-7794: IAIM Bima.

Jainuri, A. 2008,Nabdlatul Wathan Gerakan Reformasi Islam di Jawa pada Awal Abad ke20, Surabaya: Biana Ilmu.

Langgulung Hasan,1980, Beberapa Pemikiran tentang Pendidikan Islam (Bandung: alMa'arif.

Malik Fadjar, 2006, Holistika Pemikiran Pendidikan, Jakarta: Raja Grafindo Persada. Muhaimin, 2009, Paradigma Pendidikan Islam; Upaya Mengefektifkan Pendidikan Agama Islam di Sekolah. Cet. II; Bandung: PT. Remaja Rosdakarya.

Muhaimin: 2010, Pengembangan Kurikulum Pendidikan Agama Islam; Bandung: PT. Remaja Rosdakarya.

Perguruan Tinggi Universitas Nahdlatul Wathan Mataram, Sekilas Profil Perguruann Tinggi Universitas Nabdlatul Wathan Mataram.

Rahman, Getteng Abd.2009, Pendidikan Islam di Sulawesi Selatan; Tinjanan Historis dari Tradisional hingga Modern. Cet. I; Yogyakarta: Graha Guru.

Rama,Bahaking. 2007, Jejak Pembaharuan Pendidikan Pesantren (Cet. I; Jakarta: Parodatama Wiragemilang.

Tobroni: 2008, Pendidikan Islam; Paradigm Teologis, Filosofis Dan Spiritualitas, Malang: UMM press Malang.

Zainuddin Achied, 2011, Kiprah Perjuangan Nabdlatul Wathan Nusa Tenggara Barat (sebuah catatan sejarah tabun 1935-2010), Mataram: UM Mataram Press. 